\title{
Using Schoology in the Era of IR 4.0 (Factors Analysis From Students' Perception)
}

\author{
Widi Sriyanto ${ }^{1, a^{*}}$, Nita Kaniadewi $i^{1, b}$ \\ ${ }^{1}$ State Polytechnic of Creative Media, Jakarta, Indonesia; ${ }^{2}$ University of Muhammadiyah Prof. Dr. HAMKA, Jakarta, Indonesia \\ a widi.sriyanto@polimedia.ac.id; b nitakaniadewi@uhamka.ac.id \\ ${ }^{*}$ Corresponding Author \\ Whatsapp Number: [082123413157]
}

How to Cite : Sriyanto, W., Kaniadewi, N. (2019). Using Schoology in the Era of IR 4.0 (Factors Analysis From Students' Perception).. International Journal for Educational and Vocational Studies, 1 (5), 451-454

\section{ARTICLE HISTORY}

Received: 12 June 2019

Revised: 24 July 2019

Accepted: 22 August 2019

\section{KEYWORDS}

Learning Management System;

Schoology;

Students' Perception;

\section{ABSTRACT}

This study aimed to gain students' perceptions in the use of Schoology to assist their learning activities in the era of industrial revolution 4.0. This study involved four classes that applied online and offline learning systems that used Schoology in their lecture activities. This type of research is quantitative description with a factor analysis involving 100 respondents who were given a questionnaire. The instrument of the study was close-ended questionnaire that refer to several indicators such as student technology literacy, student learning styles, lecturer roles, and features of Schoology. Then, the results of this study showed that there were five important factors about the use of Schoology in facilitating their learning activities both inside and outside the classroom.

This is an open access article under the CC-BY-SA license.

\section{INTRODUCTION}

Today, the use of a computer, smartphone, and internet is like a necessity for everyone. It is because the development of technology brings ease, especially in the educational field. Moreover, rapid technological developments, especially in the era of Industrial Revolution 4.0, make learning possible anywhere and anytime, for example, by using the e-learning system. Most of the institution, such as in America, almost 90\% already used e-learning in their educational system (Basori, 2013). Horton (2003) says that e-learning utilizes internet and website which is aimed to create learning experience. It is relevant with current techonlogical which priorutuzes the use of computer and internet in daily life especially in educational field. Then, Comerchero (2006) adds that e-learning is an educational tool that covers communication, efficiency, technology and motivation. E-learning can be said as a good innovative media that support people having educational environtment wherever and whenever they are.

The most current type of e-learning is Learning Management System (LMS). Amiroh (2012) states that Learning Management System (LMS) or Course Management System (CMS), or it is called Virtual Learning Environment (VLE) is a software application that is used by educators at schools or universities as a internet based learning media (e-learning). It is a free open source that can be used for anyone to have online learning. It has been designed for the process of learning activities in the classroom, or it is commonly called virtual class. Many institutions have used LMS in helping their teaching and learning activities. Riad and El-Ghareeb (2008) add that LMS have many features for sending and managing the course because it can handle automatically such as sending learning material, quiz, and scoring.

There are many kinds of LMS, but the most popular are Moodle, Edmodo, and Schoology. Those applications can be used from elementary school to higher education. They are designed to facilitate instructors and learners to conduct the learning processes such as in the real classroom and virtual classroom. One of the LMS which is focused on this study is Schoology. Aminoto and Pathoni (2014) explain that Schoology is a website which combines e-learning and social media. It facilitates the teachers and students with many tools that can be utilized to do the learning process and to interact with each other like social media. Moreover, Juniarti (2014) also agrees that Schoology can provide teachers and learners to get involved in the interaction of learning environment like usual class.

Furthermore, Mahanani (2013) expresses that by using Schoology the teacher can sharpen the mindset of studentsto think critically and creatively. However, it needs an ability to apply it in the classroom, especially for 
the teacher. Teachers are expected to accommodate different learning paces, styles, and needs, especially in this digital native era (Santosa, 2017). The teacher should adjust the teaching style and think about the students' learning style based on the development of technology which the use of computer, internet and smartphone is the most favorite one.

Nonetheless, the development of technology, internet, and smartphone, may have a good and bad impact both for teachers and students in the context of teaching and learning process. However, the teacher should be more aware to anticipate some bad impacts of technology development. Then, the good impacts should be maximized to ease teaching and learning process which one way is by using blended learning method. Blended learning can be done by using internet and smartphone, and Schoology is suitable with blended learning because it uses internet and it can be installed on smartphone. Therefore, this study figures out its role in the teaching and learning process whether or not the application is able to facilitate and support learning activities as usual done in actual class.

Accordingly, this study proporses the following research questions:

1. What are the factors analysis that can be found form the use of Schoology in assisting teaching and learning activities?

\section{METHODS}

\subsection{Participants}

This study took the data from three study programs such as English education, Islamic education, and primary teacher. The participants were taken 100 students from first and third semester which implemented Schoology in their classroom.

\subsection{Research Design}

The research design used quantitative design that can be a fit method to answer the research questions statistically and descriptively related with the use of Schoology as learning media for students.

\subsection{Instruments and Data Collection}

A set of questionnaire was deployed to the respondents which containing some aspects such as technology literacy, learning style, role of lecturer, and features of Schoology. There were twenty-five items that were designed related with the aspects. Items on technology literacy consist of five items which measure students' ability in using technology like internet, computer, and application on smartphone.

Items on learning style and lecturer's role are set twelve items to measure kinds of learning style that they apply mostly in learning. The last aspect is about features of Schoolgy which consists of seven items. They are set to measure the ease of application from the use until the display of its. There were some procedures to complete this study; first, collecting the data. At the beginning, the respondents of this study were asked to respond open-ended and close-ended questioners' instrument by submitting in the Google form questioners' format (Likerts' ordinal scale from 1= Strongly disagree (SD), 2= Disagree (D), $3=$ Neither agree nor disagree (Neutral $/ \mathrm{N}$ ), 4= Agree (A), and $5=$ Strongly agree (SA)).

\subsection{Data Analysis}

In analyzing the data, SPSS was utilized with Bartlett Test to get the statistical data from the respondents. After all calculation and tabulation had been done, the writer analyzed the data and finished it by giving the final discussion that could prove the use of Schoology to assist learning activities.

\section{RESULTS AND DISCUSSIONS}

The first step to analyze the data was shown in the following table.

Table 1. KMO Sampling Adequacy

\begin{tabular}{rr}
\hline Value & 0.726 \\
\hline
\end{tabular}

According to the Kaiser (1974), the KMO values between 0.7 and 0.8 are good. its shows from the table above that the value is 0.726 . It means the data value for this study is good for factor analysis. Moreover, to support the data, it should be done Bartlett's test to make factor analysis working.

Table 2. Bartlett's Test

\begin{tabular}{cc}
\hline Approx. Chi-Square & 958.022 \\
\hline $\mathrm{df}$ & 210 \\
\hline Sig. & 0.00065 \\
\hline
\end{tabular}

In order to make factor analysis appropriate, the significance value should be smaller than $0.001(p<.001)$. For these data, based on table 3 the significance value is smaller than $0.001(0.00065<.001)$ or it can be said that it is highly significant. Therefore, factor analysis is appropriate.

Field (2009) explains that the first part of the factor extraction process is to determine the linear components within the data set (the eigenvectors) by calculating the eigenvalues of the R-matrix. This is aimed to determine which factors to retain and which to discard

Then, SPSS output on the table 3 lists the eigenvalues associated with each linear component (factor) before extraction, after extraction and after rotation the extraction of the data which is shown in the following table.

Tabel 3. Initial Eigen values

\begin{tabular}{crrr}
\hline Component & \multicolumn{1}{l}{ Total } & \% of Variance & \multicolumn{1}{c}{ Cumulative \% } \\
\hline 1 & 4.647 & 22.131 & 22.131 \\
\hline 2 & 3.785 & 18.025 & 40.156 \\
\hline 3 & 2.128 & 10.135 & 50.291 \\
\hline 4 & 1.442 & 6.867 & 57.158 \\
\hline 5 & 1.407 & 6.700 & 63.858 \\
\hline
\end{tabular}


Based on table 3 , it can be seen that there are five factors found in the respondent's response. The five factors are the perceptions of students about the use of LMS Schoology in learning in the IR era. 4.0.

The first factor that most students answer is about features in Schoology. The ease and sophistication provided by Schoology can make users more comfortable using it. It can be compared with related LMS like Edmodo. One interesting feature is about the attendance of students. Inside Edmodo does not have such features while on Schoology the feature exists. Because of LMS is designed to help lecturers and students to be able to conduct lectures anytime and anywhere without reducing the feeling like in actual classrooms. The feature is very important. Elly (2016) researched that discipline affects learning outcomes but not entirely learning outcomes influenced by discipline. Therefore, student participation should be monitored by the lecturer to find out the results of what has been given in lectures.

The second factor is about student literacy in the use of technology. The knowledge of students in the use of technology is high along with what Sriyanto (2018) has stated that around $73 \%$ of students have a level of technology literacy that is already qualified, especially in the use of online learning media. They only stay given a little explanation without being guided for a long time in the use of a technology. This is because current life is inseparable from technology, starting from waking up to wanting to sleep from children until their parents are surrounded by technology.

The third factor is related to student learning styles. As Hasniyati (2018) said in the era of industrial revolution 4.0 the function of lecturers is no longer as central in learning or teacher-centered, but turned into students-centered where lecturers become facilitators for the provision of learning needs of students. Thus, it changes the way students learn to be more autonomous because the facilities needed are sufficient for them. They can use the internet to access material presented by lecturers in accordance with the competencies to be achieved.

Fourth is about the role of the lecturer in learning. Although in the above explanation the function of the lecturer is not as a central learning but the role of the lecturer is also very necessary in online learning activities because in addition to being a facilitator the lecturer also acts as a source of learning. Wartomo (2016) adds the roles of lecturers in digital era are (a) learning resources; (b) facilitator; (c) manager; (d) demonstrator; (e) counselor; (f) motivator; (g) evaluator. Additionally, the closeness of the relationship between lecturers and students will be closer because they need not be ashamed to ask about anything and anything when they experience difficulties and confusion in understanding the lessons given. with the development of communication technology it is much easier and faster as when face to face.

The last factor is about face to face meeting that needs to be done. Pannen (2016) The principle of e-learning from the policy of distance education and e-learning is possible to have a face to face meeting. In addition, even though they can study anywhere and anytime using the internet. As explained in the fourth factor that the role of lecturer is one of them as a motivator. In connection with the role of the lecturer that meeting or discussion can directly foster self-confidence and increase motivation for a student's motivation in learning with authority and charisma from his lecturer when explaining material or consulting lessons.

The use of Learning Management System (LMS) is common in this digital era. Most students are familiar with a number of LMS applications, but only those who previously went to school in places that had adequate supporting facilities, especially technology.

Schoology or electronic learning systems have not been widely applied by most teachers because in their syllabus it has not been written about blended learning. Though, this should have become the vision of the instructors in addressing the development of the era, especially in the era of industrial revolution 4.0.

The existence of e-learning has become a necessity for educational institutions to implement it in their learning systems. Even though a teacher only uses a free LMS, but if the teacher can use it appropriately automatically it will help teaching and learning activities getting better.

\section{CONCLUSION}

The results of this study provide some factors analysis found based on the results of responses from respondents related to the use of LMS in helping the learning process. Schoology as a free LMS is definitely not perfect like a paid LMS, but if lecturers can take advantage of the features in it, it is not impossible that they can maximize the current learning process. The found analysis factors are useful in the development of e-learning in general or the development of Schoology in particular.

Features, technology literacy, learning styles, lecturer roles, and face-to-face meetings are factors that need to be considered in the use or development of online or e-learning teaching media. All of these factors become aspects related to each other. For example, if in Schoology there are advanced features such as video conferencing, the aspect of face-to-face meetings can be fulfilled. Even though it is difficult to hold, this can be dealt with the actual face pattern in accordance with the blended learning pattern which still combines usual and online meetings.

Therefore, the challenge for a lecturer or a teacher is very heavy in following the current technological developments. If they ignore it, surely they will not create a learning innovation needed by their students. Self-development and sensitivity to technology is an absolute thing that must be done by a teacher so that it is more useful for the wider community and certainly for his students. All in all, the authors hope that this study can be a reference for educators today in the era of industrial revolution 4.0 and can add insight to the wider community. 
Hopefully, the results of this study can be developed into better research in the future by either the researchers themselves or anyone who has an interest in technological developments in education.

\section{REFERENCES}

Aminoto, Tugiyo dan Pathoni, Hairul. (2014). Penerapan Media E-Learning Berbasis Schoology untuk Meningkatkan Aktivitas dan Hasil Belajar Materi Usaha dan Energi di Kelas XI SMA N 10 Kota Jambi. Jurnal Sainmatika. Vol 8, No. 1

Amiroh. (2012). Under E-Learning, Edmodo, Moodle and Schoology. (Online). Sumber http://amiroh.web.id. Diunduh 8 Januari 2019.

Basori. (2013). Pemanfaatan Social Learning Network Schoology dalam Membantu Perkuliahan Teori Bodi Otomotif di Prodi PTM JPTK FKIP UNS. Jurnal Ilmiah Pendidikan Teknik dan Kejuruan (JIPTEK), Vol. VI, No. 21.

Comerchero, Matthew. (2006). E-Learning Concepts and Technique. USA. Institute for Interactive Technologies, Bloomsburg University of Pennsylvania.

Elly, R. (2016). Hubungan Kedisiplinan Terhadap Hasil Belajar Siswa Kelas V Di Sd Negeri 10 Banda Aceh. Jurnal Pesona Dasar, 3(4).

Field, Andi. (2009). Discovering Statictics Using SPSS. London: SAGE Publication, Inc.

Hasniyatih, Syari. (2018). Menghadapi Revolusi Industri 4.0 Dengan Rumah Belajar. (Online). (http://pena.belajar.kemdikbud.go.id/2018/09/menghada pi-revolusi-industri-4-0-dengan-rumah-belajar/), diakses 20 April 2019

Horton, William \& Horton, Katherine. (2003). E-Learning Tools and Technologies: A consumer guide for trainers, teachers, educators, and instructional designers. USA : Wiley Publishing, Inc.

Januarti, Rani Dwi. (2014). Pengembangan media mobile learning dengan aplikasi Schoology pada pembelajaran geografi materi hidrosfer kelas X SMA Negri 1 Karanganyar. Universitas Negeri Solo.

Kaiser, H. F. (1974). An index of factorial simplicity. Psychometrika, 39, 31-36.

Mahanani. (2013). Aplikasi Schoology dalam proses pengajaran dan pembelajaran. (Online), (http://www.m-edukasi.web.id/2013/06/aplikasi-schoolo gydalam-proses.html), diakses 10 Pebruari 2019.

Riad, Alaa el-din mohamed dan Haitham El-Ghareeb. (2009). Evaluation of utilizing service oriented architecture as a suitable solution to align university management information systems and learning management systems. Turkish Online Journal of Distance Education, Vol, 10 (1). 4.

Pannen, Paulina. (2016). Kebijakan PJJ dan E-Learning. (http://kopertis3.or.id/v2/wp-content/uploads/Paulina-P annen-Kebijakan-PJJ-dan-E-Learning.pdf) diakses 20 Pebruari 2019.
EFL Gen Z students in a Flipped Learning context. Journal on English as a Foreign Language, 7(2), 183-208.

Sicat, Alvin S. (2015). Enhancing College Students' Proficiency in Business Writing Via Schoology. International Journal of Education and Research, Vol, 3(1). 162.

Sriyanto, W. (2018). Edmodo Dalam Pembelajaran Grammar Dan Tingkat Literasi Teknologi Mahasiswa. Prosiding Seminar Nasional Pendidikan, (2004), 433-448. Retrieved from https://jurnal.umj.ac.id/index.php/SNP/article/view/284 0

Wartomo. (2016). Peran Guru Dalam Pembelajaran Era Digital. Prosiding Temu Ilmiah Nasional Guru (TING), (2009), 265-275. Retrieved from https://repository.ut.ac.id/6500/1/TING2016ST1-26.pdf

Santosa, M. H. (2017). Learning approaches of Indonesian 